\title{
$\mathbf{X}$ 線顕微鏡による生物試料の観察
}

\author{
渡辺紀生*, 木 原 裕** \\ * 名古屋大学理学部物理教室, 名古屋市千種区不老町 ( 4464$)$ \\ ** 自治医大看護短大，栃木県河内郡南河内町薬師寺 3311-159 (广329-04)
}

(1991 年 3 月 1 日受理)

\section{Observation of Biological Specimen with X-ray Microscopy}

\author{
Norio WatanabE*, Hiroshi KiHARA** \\ * Departmet of Physics, Faculty of Science, Nagoya University, Furo, Chikusa-ku, Nagoya 464 \\ ** Jichi Medical School, School of Nursing, M!namikrwachi, Tochigi 329-04
}

(Received March, 1, 1991)

\begin{abstract}
Several methods in the development of X-ray microscopy were tested, including the imaging method with zone plates and grazing-incidence mirrors. With zone plates, spatial resolution of $0.5 \mu \mathrm{m}$ was attained. With grazing incidence mirrors, the spatial resolution of $0.2 \mu \mathrm{m}$ was achieved. With both methods, zone plates, diatoms, muscle, collagen and other biological specimen were observed.

As a compact X-ray source, AURORA seems to be promising. We have tested contact X-ray microscopy of Hela cell and chromosomes. With $10 \mathrm{~s}$ exposure (ring current $\sim 2 \mathrm{~mA}$ ), good contrast image was taken.

Spatial resolution was about several tens $\mathrm{nm}$. Points to be improved were discussed for each method.
\end{abstract}

\section{1. はじめに}

$\mathrm{X}$ 線湿微鏡は,「(i) 光学顕微鏡に比べて波長が短いの で，より高い空間分解能が期待できる。(ii) 電子顕微鏡 に比べて水中で見えること，染色の必要がないこと，よ り厚い ( 数 $\mu \mathrm{m})$ 試料の測定ができること, の特徴が あるため，生きた細胞をとのます観察することができる 点で優れている。（iii）重原子などによるラベルをする ことにより，特定物質のミクロ分布を観察することがで きる.」なぞの特徴がある.

筆者らは 7,8 年前よりX線顕微鏡を開発し，生きた 細胞，超分子構造と機能などを観察したいと様々な試み を続けてきた。この報文では, 最初に簡単に一般的な $\mathrm{X}$
線影微鏡の解説を行い, 続いて筆者らのX線顕微鏡につ いての最近の成果をサマリーしてみたい。な和 $\mathrm{X}$ 線顕微 鏡についての，より一般的な解説については, 文献 1 , 2,15 を参照されたい。な拉X線顕微鏡の国際会議が 3 年に一度開催され, それらの報告集が単行本として出版 されており方，またその間に開かれた国際会議の報告 も別に出版されているので,7)，それぞれの方法につい いて詳しく知りたい方はこちらを参照されたい.

\section{X 線顕徵鏡の方法}

$\mathrm{X}$ 線顕微鏡とは $\mathrm{X}$ 線を用いて微小なものを見る方法の 総称で, 光学顕微鏡々同様に種々の方法がある.それら はそれぞれ特徵があり, 単純な優劣はつけがたい. 表 1 
表 1 種々の X 線䡩微法の比較

\begin{tabular}{|c|c|c|c|c|c|c|c|}
\hline 方法 & $\begin{array}{c}\text { 分解能 } \\
(\mathrm{nm})\end{array}$ & $\begin{array}{l}\text { 波長 } \\
\text { 分解能 }\end{array}$ & 集光効率 & 実時間湘定 & 立体 & 光源 & 国内研究者 \\
\hline 結像型 & & & & & 可能 & & \\
\hline ゾーンプレート法 & 40 & あり & $<12 \%$ & 可能 & & SR & 有留, 籠島, 木原 \\
\hline Wolter 型斜入射鏡 & 300 & なし & $100 \%$ & 可能 & & SR & 青木, 木原 \\
\hline \multicolumn{8}{|l|}{ Kirkpatrick-Baetz } \\
\hline 型斜・射鏡 & 1500 & なし & $100 \%$ & 可能 & & SR & 鈴木 ${ }^{17)}$ \\
\hline Schwarzschild 型鏡 & 500 & なし & $\sim 1 \%$ & 可能 & & LASER & 田中 \\
\hline 走査型 & & & & & 可能 & & \\
\hline $\begin{array}{c}\text { ゾーンプレート型 } \\
(1 \text { 枚 })\end{array}$ & 40 & あり & $100 \%$ & 不向き & & SR & \\
\hline Wolter 型斜入射鏡 & 300 & なし & $100 \%$ & 不向き & & LASER & 早川15) \\
\hline Schwarzschild 型鏡 & & あり & $100 \%$ & 不向き & & LASER & \\
\hline 投影法 & 200 & なし & $100 \%$ & 不向き & 可能 & 点光源 & 矢田 \\
\hline 光電変換型 & 200 & なし & $\sim 10 \%$ & 可能 & & SR & 木原 \\
\hline 密着法 & 20 & なし & & 不可能 & 可能 & SR & 篠原 \\
\hline & & & & フラッシュ法 & & フラッシュ X線 & 篠原 \\
\hline ホログラフィー & 100 & なし & & 不向き & 最適 & SR & \\
\hline ミクロC T & 2000 & なし & & 不向き & 最適 & SR & 鈴木 ${ }^{18)}$ \\
\hline
\end{tabular}

国内研究者の発表については，特に記したもの以外は，文献 5 を参照されたい，

にそれぞれの特徴を要約して示す．国内でもX線顕微鏡 を開発しようという試及が，いくつかのグループによっ てなされてきている。それらについてもあわせて表 1 に まとめておいた。

\section{3. 我々の試みてきた方法}

我々は 7,8 年前からいくつかの方法により, X線湿

表 2 今までに行ったX線顕微鏡の測定法と線源

\begin{tabular}{ll}
\hline \multicolumn{1}{c}{ 結像法 } & \multicolumn{1}{c}{ 線源 } \\
\hline ゾーンプレート法 & UVSOR 6A1, 8A \\
斜入射鏡法 & UVSOR 8A \\
ユンタクト法 & AURORA \\
\hline X線ズーミング管 & PF 11A \\
\hline
\end{tabular}

微鏡の開発を試みてきた，表 2 亿とれらの方法と場所と をまとめて示す，以下，それらの試みについて順に述へ よう、な抗ここで述べている研究の一部については，既 に別の場所飞報告してあるので詳しくはそちらを参照し ていただきたい、年)。

\section{4. ゾーンプレート法}

ゾーンプレートを用いた結像の試みは, 1987 年より 分子科学研究所の UVSOR 研究施設を利用して行って きた，用いたン゙ーンプレートの特性表を表 3 に示す。表 の中で HZP1 は波長 $1.76 \mathrm{~nm}$ で位相ゾーンプレートに なる、ゾーンプレートの空間分解能をレーリー飞従って $1.22 * d r_{n}$ で定義すると, 表 3 のそれぞれのゾーンプレ ートの理論的空間分解能は計算できるわけである. 現在

表 3 ゾーンプレート特性表

\begin{tabular}{|c|c|c|c|c|c|c|c|c|c|c|}
\hline & $\begin{array}{c}r_{1} \\
(\mu \mathrm{m})\end{array}$ & $\underset{(\mu \mathrm{m})}{D}$ & $n$ & $\begin{array}{c}d r_{n} \\
(\mu \mathrm{m})\end{array}$ & $\begin{array}{c}\text { 焦点距離 } \\
(\lambda=4.5 \mathrm{~nm})\end{array}$ & $\begin{array}{l}\text { マスク } \\
(\mu \mathrm{m} \phi)\end{array}$ & コメント & 材質 & $\begin{array}{l}\text { 厚さ } \\
(\mu \mathrm{m})\end{array}$ & 製造者 \\
\hline CZP1 & 34.6 & 1220 & 312 & 0.98 & 266.7 & 200 & Free-standing & $\mathrm{Au}$ & 2 & CANON \\
\hline $\mathrm{CZP} 2$ & 34.6 & 1220 & 312 & 0.98 & 266.7 & No & Free-standing & $\mathrm{Au}$ & 2 & CANON \\
\hline CZP3 & 15.82 & 500 & 250 & 0.50 & 55.6 & 100 & $0.3 \mu$ polyimide & $\mathrm{Au}$ & 0.3 & CANON \\
\hline MZP1 & 27.3 & 1492 & 746 & 0.50 & 166.0 & No & $1.5 \mu \mathrm{SiC}$ & $\mathrm{W} / \mathrm{Ti}$ & 0.5 & 三菱電機 \\
\hline MZP2 & 9.4 & 117.4 & 89 & 0.50 & 19.7 & No & $1.5 \mu \mathrm{SiC}$ & $\mathrm{W} / \mathrm{Ti}$ & 0.5 & 三菱電機 \\
\hline $\mathrm{HZP} 1$ & 9.38 & 212 & 128 & 0.40 & 19.6 & No & Free-standing & $\mathrm{Au}$ & 0.5 & Heidenhein \\
\hline $\mathrm{HZP} 2$ & 9.38 & 212 & 128 & 0.40 & 19.6 & No & Free-standing & $\mathrm{Ni}$ & 0.43 & Heidenhein \\
\hline $\mathrm{HZP} 3$ & 32.7 & 2400 & 1350 & 0.44 & 23.8 & Yes & Free-standing & $\mathrm{Au}$ & 9.5 & Heidenhein \\
\hline
\end{tabular}

$r_{1}$ : 最内輪帯半径, $D:$ ゾーンプレート直径, $n$ : ゾーン本数, $d r_{n}$ : 最外輪帯幅 


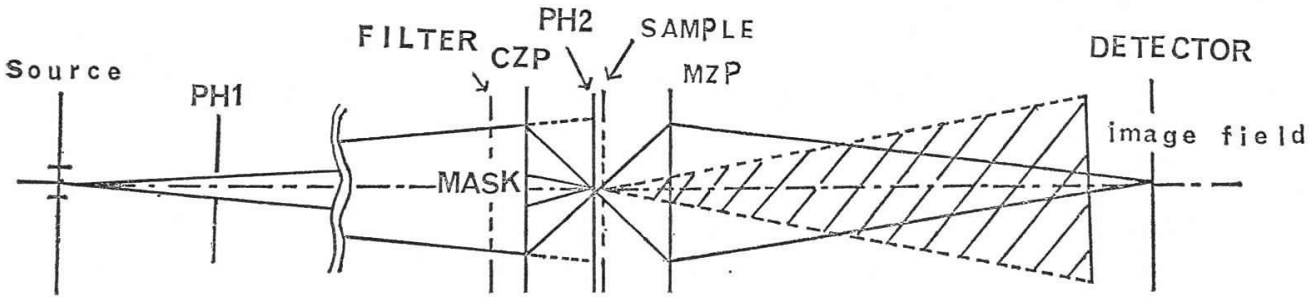

図 1 ゾーンプレートを用いた結像法のシステム図.

表 4 ゾーンプレート法によるX線㩆微鏡システム特性表

\begin{tabular}{|c|c|c|c|c|c|c|}
\hline No. & 集光/分光 & 結像 & $\begin{array}{l}\text { 波長 } \\
(\mathrm{nm})\end{array}$ & 倍率 & $\begin{array}{c}\text { 分解能 } \\
(\mu \mathrm{m})\end{array}$ & 備考 (試料) \\
\hline 1 & 分光器 & CZP1 & 10.5 & 10 & 数 & \#1000 メッシュ \\
\hline 2 & CZP1 & CZP2 & 6.0 & 13.4 & 数 & ゾーンプレートの熱損傷 \\
\hline 3 & CZP3 & CZP3 & 4.74 & 43.7 & 1.5 & メッシュ, ゾーソプレート \\
\hline 4 & MZP1 & MZP2 & 1.7 & 50 & 1.0 & ゾーンプレート, 珪藻土 \\
\hline 5 & CZP3 & (HZP1, HZP2) & 1.76 & 47 & 1.2 & 位相ゾーンプレートのテスト \\
\hline 6 & MZP1 & HZP1 & 1.76 & 70 & 0.55 & 珪藻，コラーゲンなど \\
\hline
\end{tabular}

使用しらるゾーンプレートの中で最も空間分解能が高い のは HZP1 と HZP2 でそれぞれ $0.5 \mu \mathrm{m}$ である.

表 4 亿今までに行ってきた実験を要約して示す。光源 としては分子科学研究所の UVSOR を用いた。拉もに 用いたビームライン $8 \mathrm{~A} 1$ は光学系のない白色光ライン である. No. 1 の場合を除いていずれの場合も図 1 亿示 すように 2 枚のゾーンプレートをそれぞれ集光用，結像 用に用いた，集光用のゾーンプレート (CZP) には入射 する0次光をカットするために中心にマスクをつけた， 入射X線は光源を小さくするためにピンホール (PH1) を通し、フィルターでカットしたのb, 集光用ゾーンプ レート (CZP) で集光させる. 集光点にピンホール $(\mathrm{PH} 2)$ を执いて分光し，試料を照射する。結像用ゾーンプレー ト(MZP) を通ったのち, 結像面に㧍かれたマルチチャ ンネルプレート (MCP) で線を受故, 蛍光スクリーンに 写った像をSIT カメラで，(浜松ホトニクス）モニター し, データ処理装置 (ARGUS100, 浜松ホトニクス) を 経てモニター TV 上で観察した。 光軸調整, 測定はほ とえど実時間または 1 秒程度の積算で行った。

\section{1. 位相ゾーンプレートのテスト ${ }^{10)}$}

計算によれば，今回の実験で MZP として用いた位相 ゾーンプレート (HZP1) の透過率の計算值は, $16.4 \%$ で，同じサイズで位相型になっていない振幅型のゾーン プレートである HZP2 に比べて強度比が 2.6 倍になる 筈であった，実際の我々の測定では透過率が $8 \%, 1.6$ 倍であった ${ }^{10)}$.それぞれの值が理論予測值には及んでい
ないが，主な原因はこの時の波長分解能 $(\lambda / \Delta \lambda)$ が 7.4 と不十分であった事によると思われる。理論計算の時に は, 単色光 (波長分解能は無限大) を仮定しており, そ の点を考慮すれば位相型のゾーンプレートは注ぼ設計通 りに働いたといえよう。

\section{2. 結像法による像観察}

我々はこの数年間に, 表 4 亿示すよう種々のゾーン プレートを用いて結像テストを行った. 現在の所, MZP1-HZP1 系で観察した $0.55 \mu \mathrm{m}$ の分解能が最も優 れた結果を示している14). 図 2 とこの組合せで得た結果 の中から、ゾーンプレート自身を試料として観察した例 を示す、ゾーンプレート法は世界的には最も分解能が高 く, Schmahl (Gottingen 大学) らによって古くから開

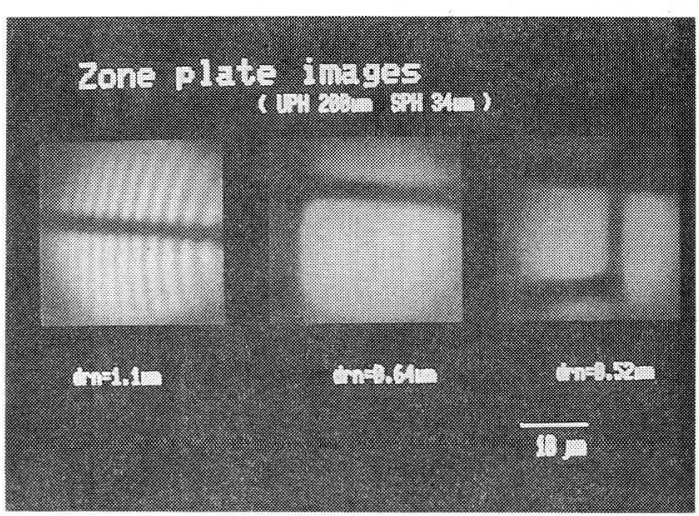

図 2 ゾーンプレート法で撮影したゾーンプレート． 
発されてきた方法である ${ }^{19}$. 表 1 亿る示したように現在 $40 \mathrm{~nm}$ の分解能でウェットな染色体の像が撮影されてい る20). 我々の場合, 用いているゾーンプレートから予測 される分解能は最外ゾーン幅が $0.41 \mu \mathrm{m}$ を用いて, $1.22 * 0.41 \cdot \mu \mathrm{m}=0.5 \mu \mathrm{m}$ で, いま得られた分解能はほ ぼ理論值と同じになっている. No. 6 以外の実験の場合 に, 理論的に予測される分解能までに至らなかったのは ゾーンプレートそのものが理想的な状態でなかったか, 分光が充分でなかったことによると思われる.

\section{3. 今後の課題}

1）水中での測定 我々が今回測定したのは真空中に おいたドライな試料だけであるが，X線顕微鏡の最も重 要な特徵の一つは水の中でも（生きた状態で測定するた めには必須の条件であるが) 測定できることであるの でなるべく早期に水中の試料を入れられる試料槽を開 発したい，世界的にはすでに水中の試料の測定例は報告 されており 20,21), 国内でもコンタクト法については, 篠 原 ${ }^{222}$, 富江 ${ }^{23)} ら か ゙$ 既に水中での測定の結果を報告してい る.

2) 空間分解能の改善 るっと空間分解能の高いX線 顕微鏡を開発するためには, さらに分解能の高いゾーン プレートの製作が望まれる。世界的には Lawrence Berkeley のAttwood らが, 最外輪帯幅 $\left(d r_{n}\right)$ が 30 $\mathrm{nm}$ のゾーンプレートをつくることに成功したと報告し ている24).

\section{5. 斜入射鏡法}

\section{1. 現在のシステム}

1985 年以来, 我々は浜松ホトニクス研究部と協力し てWolter I 型の斜入射鏡を用いたX $\mathrm{X}$ 線顕微鏡システム を開発してきた ${ }^{11)}$. 図 3 に系の概念図を示す。鏡は, 斜 入射角 $26.2 \mathrm{mrad}$ のものを用い, 倍率 20 倍倍定し た。この倍率はそんなに高いものではないが，後述する $\mathrm{X}$ 線ズーミング管と併用することにより, $10 \mathrm{~nm}$ の分解 能までは使用しうる(X線ズーミング管の検出面での分 解能は $0.2 \mu$ である). 光源には UVSOR のビームラ

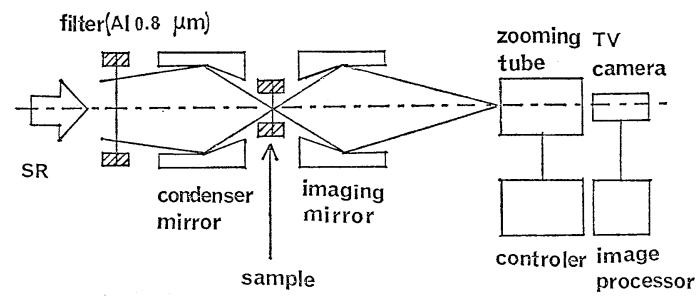

図 3 斜入射鏡を用いたX線顕微鏡のシステム図.
イン 8A1 (白色光ライン)を用いた. 今回の実験では波 長についてはフィルターでカットするだけで比較的ブロ 一ドな光を用いている、入射光は 1 枚目の斜入射鏡で集 光され，発散角を大きくする. 集光された点に試料をお き，2枚目の斜入射鏡で結像させる。系の空間分解能は 斜入射鏡の表面粗さと形状精度によって決的られる。一 般に短波長側では表面粗さが, 長波長側では形状精度が より大きい影響を及ぼす。設計值からは10 nm 近辺で $50 \mathrm{~nm}$ の分解能が得られるはずである.

この方式の特徵は (i) 全反射を利用しているため, 光 学系に波長依存性がなく, 種々の波長での測定が可能で

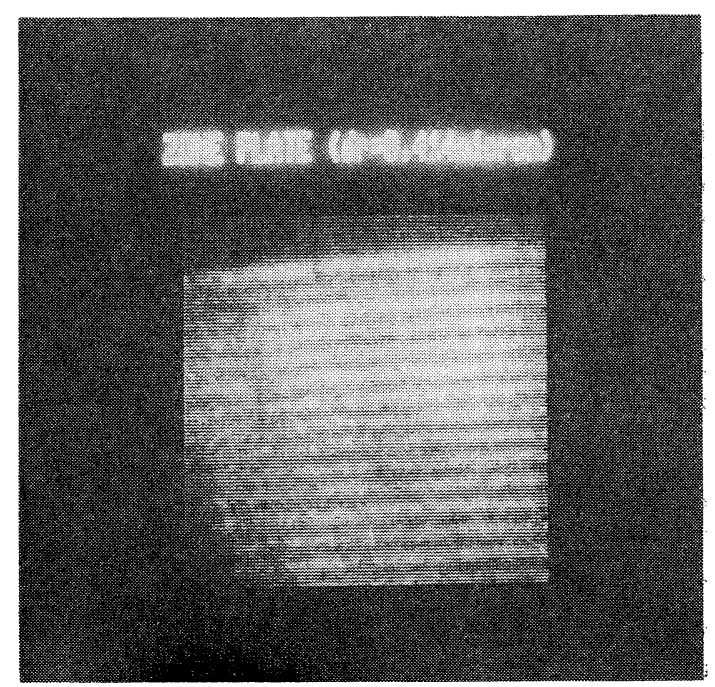

図 4 斜入射法で撮影したゾーンプレート.

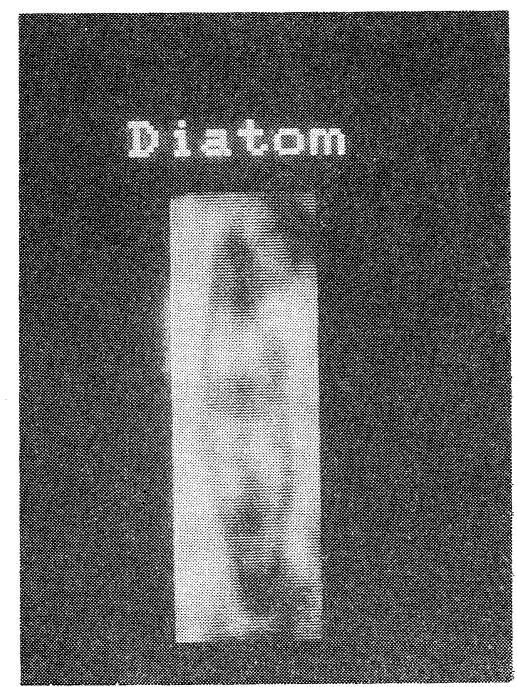

図 5 斜入射法で撮影した珪藻土. 


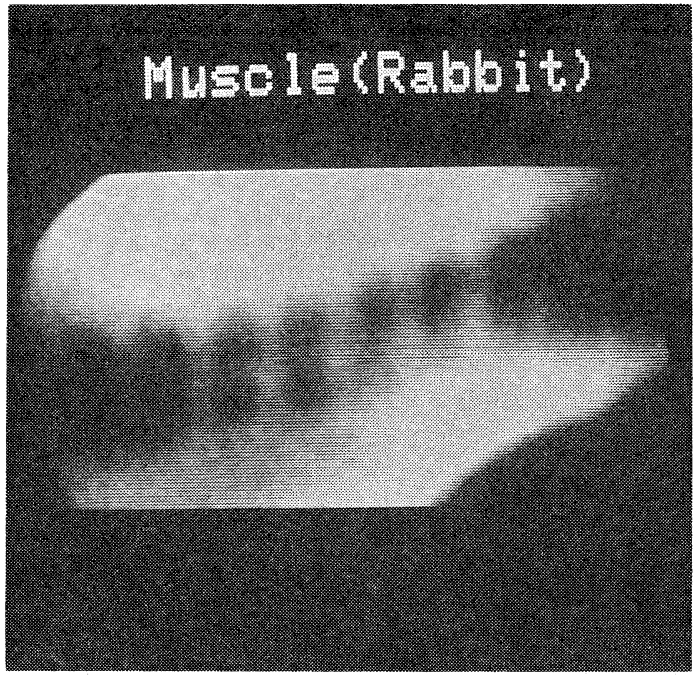

図 6 斜入射法で撮影した筋肉.

ある。特に軟X線領域と可視光とで生体試料の同じ場所 を観察することができれば，大変興味深い（（ii）検出器 としてズーミング管を用いることにより，ズーム，時間 分解測定などが可能となる.

\section{2. 測定結果}

1989 年から 90 年にかけて, 我々は分子研の UVSOR で様々なテストを抗こなった，図4 亿ゾーンプレートを 試料として観察した場合の撮影像の例を示す。これらの 像から予測される空間分解能は $0.2 \sim 0.3 \mu$ 位であるう と思われる。図 5 , 図 6 に, この方式で得られた珪藻 土, 筇肉の撮像例を示す。 その他今までにコラーダン緎 維，染色体などの撮影を行った。

\section{3. 今後の課題}

斜入射鏡を用いたX線湿微鏡の場合もゾーンプレート の場合之同様に, 今後の課題としては (i) 観察面全体に アーティファクトのないきれいな画像を得ること，(ii) 分解能を更にあげること (iii) ウェットな試料が観察す るための試料槽をつくること，が上げられる。

斜入射鏡法はゾーンプレート法に比べて, システムに 波長依存性がないこと，より少ない光量で結像させるこ とができることという特徵がある．特に後者の特徵を生 かすと, SR 光ではない実験室レベルの線源と結合し て，テーブルトップ型の $\mathrm{X}$ 線湿徵鏡をつくることが可能 になろう。我々は浜松ホトニクスとの共同研究により, ガスパフ線源を用いた実験室用 X線䫓微鏡の開発にも取 り組んでおり，現在メッシュのイメージングに成功した 段階である.

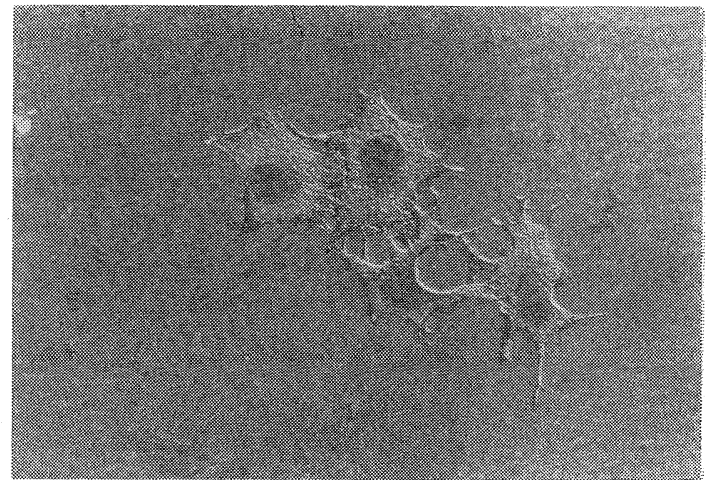

図 7 AURORA を用いて撮影した Hela 細胞.

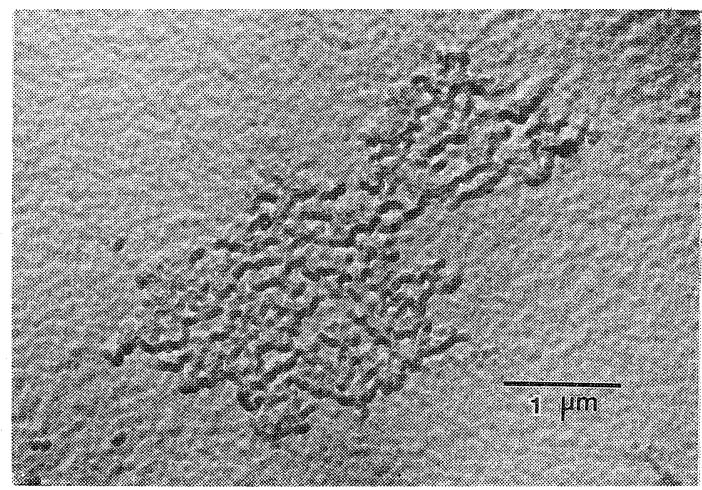

図 8 AURORA を用いて撮影した染色体 ${ }^{22)}$.

\section{6. コンタクト法}

住友重機が開発した AURORA は，コンパクトな SR 光としてX線顥微鏡の光源として子期待されている.我 々はこれを用いて，コンタクト型の $\mathrm{X}$ 線顕微法を試み た ${ }^{12)}$.リング電流が数 $\mathrm{mA}$ であったが， 20 秒の露光で 充分感度を示すレジスト像を得ることができた。試料と して Hela 細胞と染色体のイメージを撮影することに成 功した．分光しないSR 光をそのまま用いたが，分解能 は数十 nm は保証されているように思われる ${ }^{12)}$. 図 7， 8 亿旮学れの撮影例を示す。

\section{7. 直入射反射鏡法}

AURORA 注その後入射用マイクロトロンの改良を重 ね, 現在 $300 \mathrm{~mA}$ の電流が蓄積可能になった。我々はこ のようなコンパクト SR 線源に向いたシステムとして Schwarzschild 型の直入射反射鏡を用いる方式を考元， 系を設計した。図 9 にとのシステム概念図を示す，波長 は $13.5 \mathrm{~nm}$ で設計值によると分解能は $0.1 \mu \mathrm{m}$ より良 


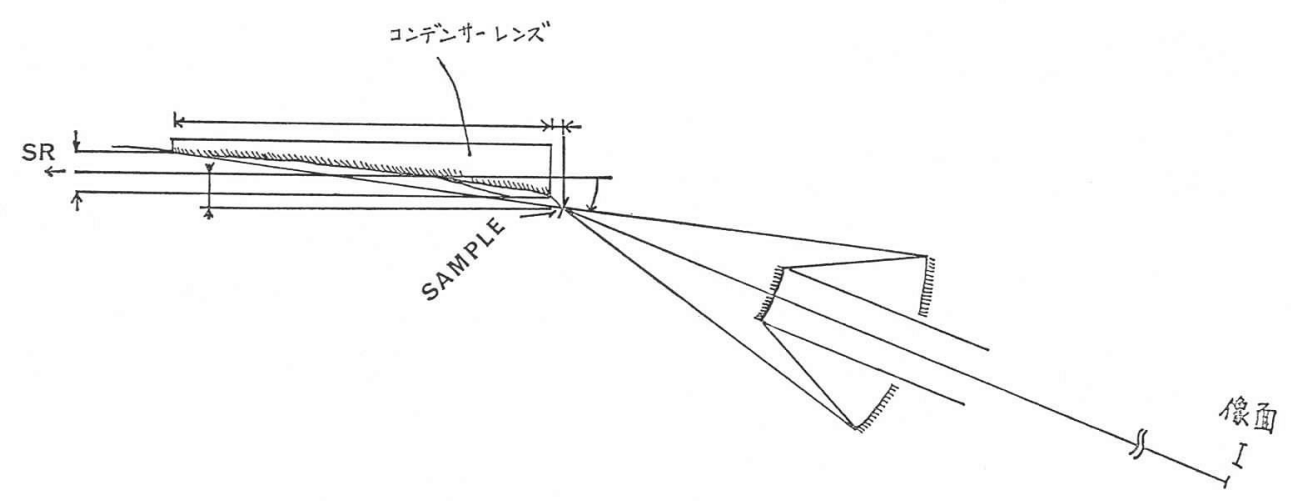

図 9 Schwarzschild 型反射鏡を用いたX線顕微鏡システム原理図。

\section{X 線ズーミング管 ${ }^{13)}$}

X線ズーミング管は，CsI，Auなどを塗布した面に X 線が当たったとき放出される 2 次電子を電磁レンズで拡 大してその後にマルチチャンネルプレート (MCP) で検 出するX線顕微鏡の検出器の 1 種である。 ズーミング管 は次に上げるいくつかの特徵を有するために, 特に注目 を集めている検出器である。

!）実時間測定が可能である.

ii）検出面の空間分解能が高い.

iii）観察中に倍率や視野を変えて測定することができ る.

我々はいままでこのズーミング管について，より定量的 に, 研究するために次のよらな実験を行った。

(イ）量子効率と検出効率のテスト

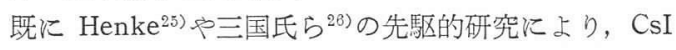
などの物質では量子効率 (=検出電子数/入射 $\mathrm{X}$ 線光子

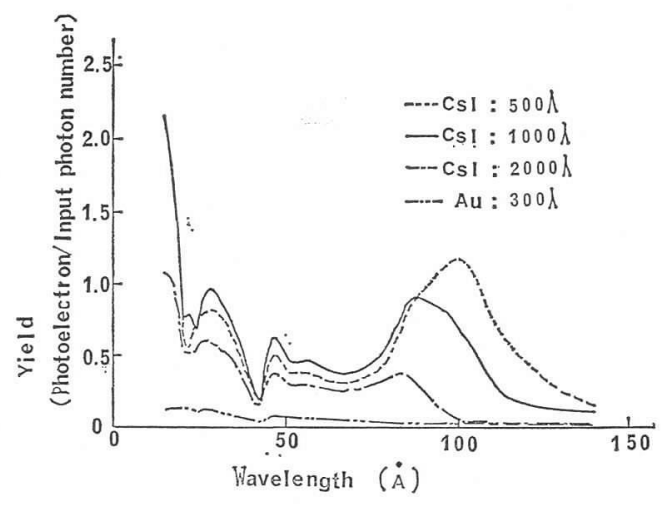

図 $10 \mathrm{Au}$ と CsI を用いた光電面の量子効率の波長 依存性

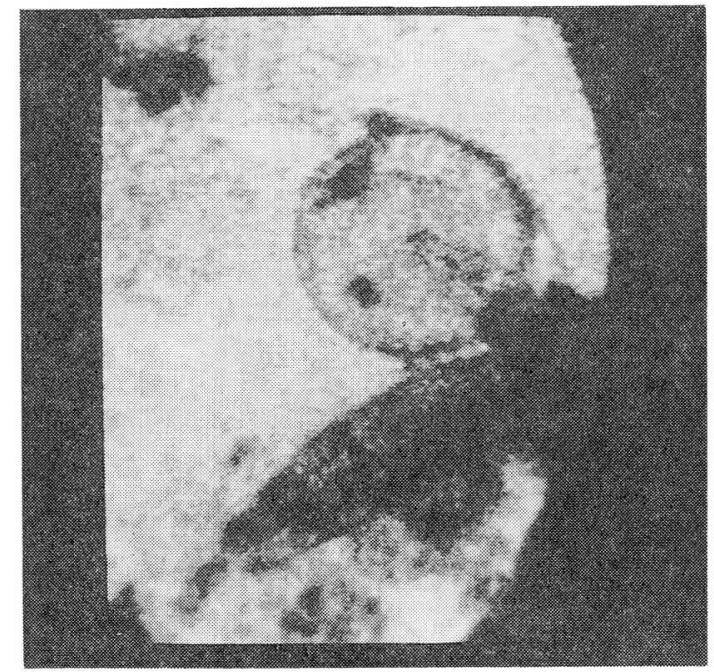

(a) $43 \mathrm{~A}$

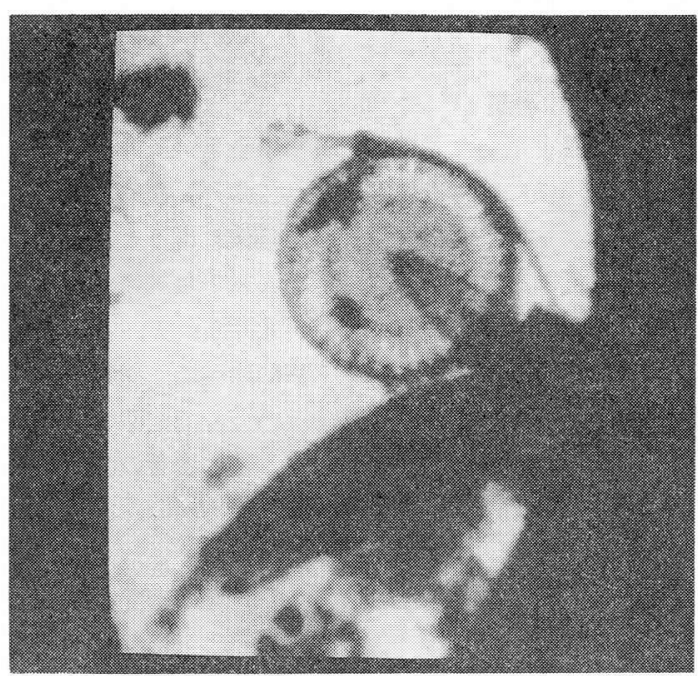

(b) $45 \mathrm{~A}$

図 11 ズーミング管で撮影した珪藻土. 


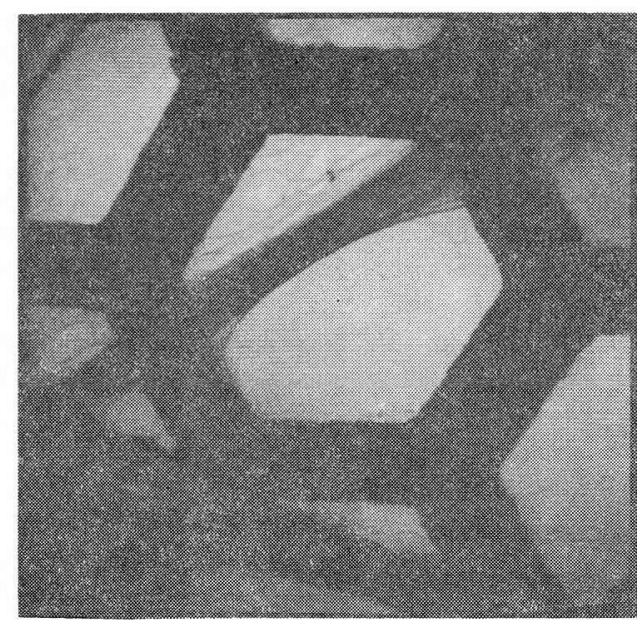

(a) 53 倍

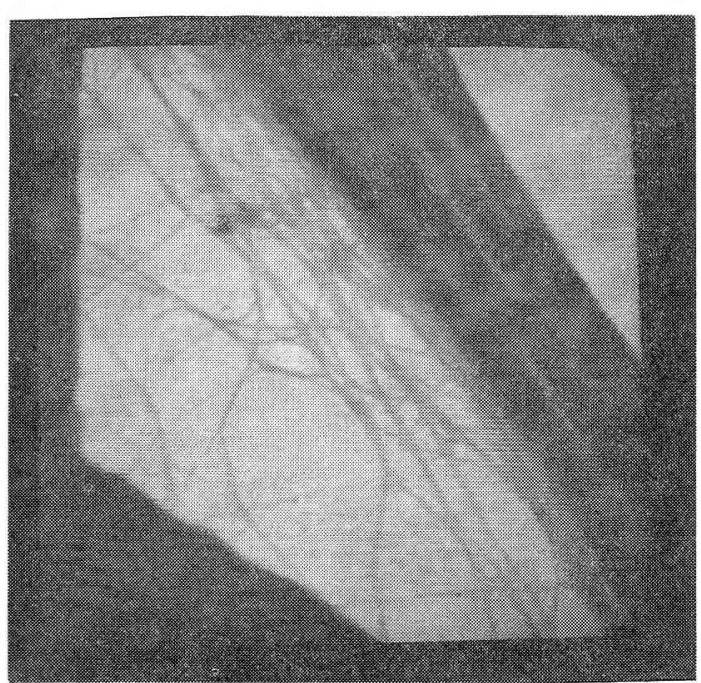

(b) 200 倍

数）が 1 を越す場合もあり，きわめて有望な方法である ことが報告されていた，我々は高エネルギー研放射光研 究施設のビームムライン $11 \mathrm{~A} を$ を使って Auを薄く塗布 した上に CsI を重权て塗り， $1.5 \mathrm{~nm}$ から $15 \mathrm{~nm}$ の範 囲で量子効率を測定した。气の結果は図 10 に示すよう に波長によっては 1 を越すことが分かった。検出効率 （二検出に捉えられたX線光子数/入射 X線光子数）は初 歩的な測定結果ではあるが，10２0\% ぐらいと推測さ れる結果を得た。これは予想を上回り，きわめて有望な 数值であると思われる。

（口）空間分解能のテスト

X線ズーミング管の最も優れた特徴の一つはその検出 面上での空間分解能の高さである。我々はこれをょり実

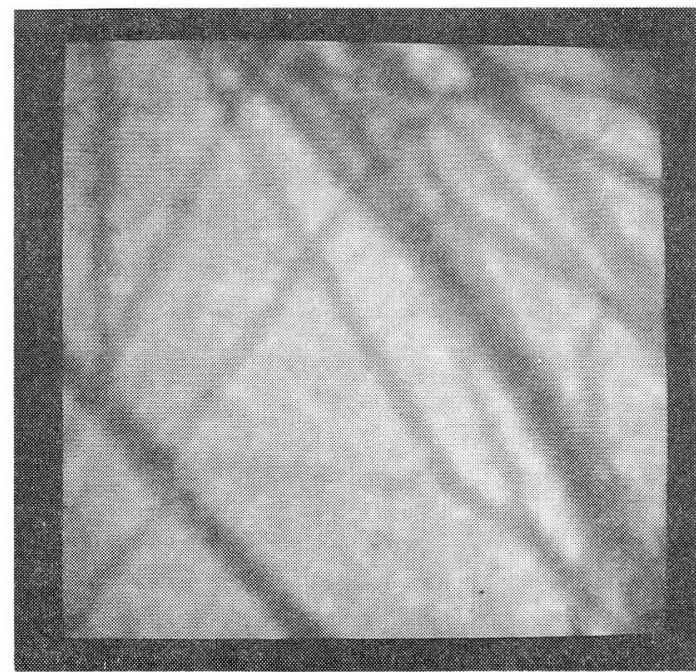

(c) 600 倍

図 12 ズーミング管で撮影したュラーゲン繊維。同 一場所を桩大倍率を変えて測定したもの波長 $10 \mathrm{~nm}$.

践的に測定するために, 生物試料を光電面に密着させて おき，その像を撮影した。試料としては珪藻土、 コラー ゲン，神経細胞，ナマコの骨片など様々なものを用いた が，特に珪藻土の試料を用いたとき，空間分解能 $0.2 \mu$ で像を観察することに成功した。図 11 に撮影例を示す。 試料を載せたなま，波長の掃引を行ったところ，炭素の 吸収端の前後で著しい像のコントラストの差異が生じる ことを見いだした。 コントラストは炭素の吸収端より長 い側でより強くなっており, 波長掃引が新しい情報を引 き出す好例かと思われる。

(八) ズーム機能のテスト

ズーム機能を持つことは, X線ズーミング管の最大の 特徽の一つである。，它の観察例を図 12 亿示す。

\section{9. 総合的考察}

本論文では私がこの数年の間に多くの共同研究者之共 に試みてきたX線顕微鏡開発の試みについてそれぞれの 方法を比較しながら，簡単にまとめて報告した， $10 \mathrm{~nm}$ の分解能で生物の運動しているところを観察しょうとい ら本来のゴールからいらとまだ距離はあるが， 1 年の単 位で考觉ると毎年着実に進んでいる。

現在までに試みてきた方法のどれが優れているかを議 論するのはなかなか難しい問題である. 光学素子の作製 の難易度などさまざまの因子を考慮すると、ゾーンプレ 一ト法は最も分解能の高い(少なくとも現在の世界的レ 
ベルでは）方法であり，斜入射鏡法はテーブルトップ型 のX線顕微鏡に向いた方法であろう. Schwarzschild 法 は波長を固定して, 通常の光学顕微鏡のようにルーチン で使用する X 線顕微鏡として最も向いていると思われ る.今の段階ではそれぞれの方法がそれぞれの特徵を生 かしながら開発されるのが望ましいと思われる。

生物試料の測定は既にかなり行われつつある. 生物学 的に重要な発見が X線顕微鏡によってなされるのもそう 遠くない時期にくるのではないか.

\section{謝辞}

本研究は, 多くの方々と協力で行われているもので あり，ここに謝意を表する次第である，文献の項に上げ た力々および分子科学研究所 UVSOR, 高エネルギー物 理研究所放射光研究施設, 住友重機械工業株式会社の AURORA を使用させていただいた事にかんし，特に感 謝したい.

\section{参考文献}

1) 木原 裕: 限界を越える顕微鏡（宝谷紘一，木下 一彦編) (学会出版センター), 印刷中

2) J. Kirz, D. Sayer, G. Schmahl, and M. Howells (永井喜則，木原 裕訳)：パリティ, 1, 4 (1986).

3) X-Ray Microscopy: ed. G. Schmahl and D. Rudolph, (Springer-Verlag, 1984).

4) X-ray Microscopy II: ed. D. Sayre, M. Howells, J. Kirz and H. Rarback (SpringerVerlag, 1988).

5) X-ray Microscopy III: ed. A. G. Michette, P. J. Duke and R. E. Burge (Springer-Verlag, in press).

6) X-ray Microscopy, Instrumentation and Biologscal Application: ed. P. C. Cheng and G. J. Jan (Springer-Verlag, 1987).

7) X-ray Microscopy in Biology and Medicine: ed. K. Shinohara, K. Yada, T. Saito and H. Kihara, (Japan Sci. Press, 1990).

8) 木原 裕: 文部省科学研究費総合研 A (究矢田慶 治代表）報告書 p.92（1990）。

9) N. Watanabe, M. Taniguchi, Y. Shimanuki, K. Kawasaki, Y. Watanabe, Y. Nagai. and H. Kihara: X-ray Microscopy III (SpringerVerlag, Berlin) in press.
10) H. Fujisaki, N. Nakagiri, H. Kihara, N. Watanabe, Y. Shimanuki, and Y. Nagai: X-ray Microscopy III (Springer-Verlag, Berlin) in press.

11) S. Ohsuka, A. Ohba, M. Sugiyama, T. Hayakawa, T. Matsumura, K. Kinoshita, N. Wata ${ }^{-}$ nabe, Y. Shimanuki, Y. Sano, and H. Kihara: X-ray Microscopy III Springer-Verlag, Berlin) in press.

12) H. Yamada, H. Nakabushi, Y. Kinjo. K. Shinohara, N. Watanabe, and H. Kihara: Xray Microscopy III (Springer-Verlag, Berlin) in press.

13) K. Kinoshita, T. Matsumura, Y. Inagaki, N. Hirai, M. Sugiyama, H. Kihara, N. Watanabe, Y. Shimanuki, and A. Yagishita: X-ray Microscopy III (Springer-Verlag, Berlin) in press.

14）渡辺紀生ら：未発表

15) M. Howells, J. Kirz. and D. Sayre: Sci. Amer., Feb. 42 (1991).

16) S. Hayakawa, A. Iida, S. Aoki, and Y. Gohshi: Rev. Sci. Instr., 60, 2452 (1989).

17）鈴木芳生：私信.

18) Y. Suzuki, T. Hirano, and K. Usami: X-Ray Microscopy in Biology and Medicine, ed. K. Shinohara et al. (Japan Sci. Soc. Press, Tokyo) p. 179 .

19) D. Rudolph and G. Schmahl: Annals N. Y. Acad. Sci., 342, 94.

20) P. Guttmann, G. Schneider, M. Robert-Nicoud, B. Niemann, D. Rudolph, J. Thieme, T. Jovin, and G. Schmahl: X-ray Microscopy III (Springer-Verlag, Berlin), in press.

21) S. Williams, C. Jacobsen, J. Kirz, S. Lamm, and J. Van't Hof: X-ray Microscopy III (Springer-Verlag, Berlin), in press.

22) K. Shinohara, A. Ito, Y. Kinjo, M. Watanabe, Y. Kikuchi, and K. A. Tanaka: X-ray Microscopy III (Springer-Verlag, Berlin), in press.

23) T. Tomie, H. Shimizu, T. Majima, M. Yamada, T. Kanayama, H. Kondo, M. Yano, and M. Ono: Science, 252, 691 (1991).

24) E. H. Anderson, and K. Kern: X-ray Microscopy III (Springer-Verlag, Berlin), in press.

25) B. L. Henke, J. P. Knauer, and K. Premaratne: J. Appl. Phys.,., 52, 1509 (1981).

26) 三国 晃ら：私信. 